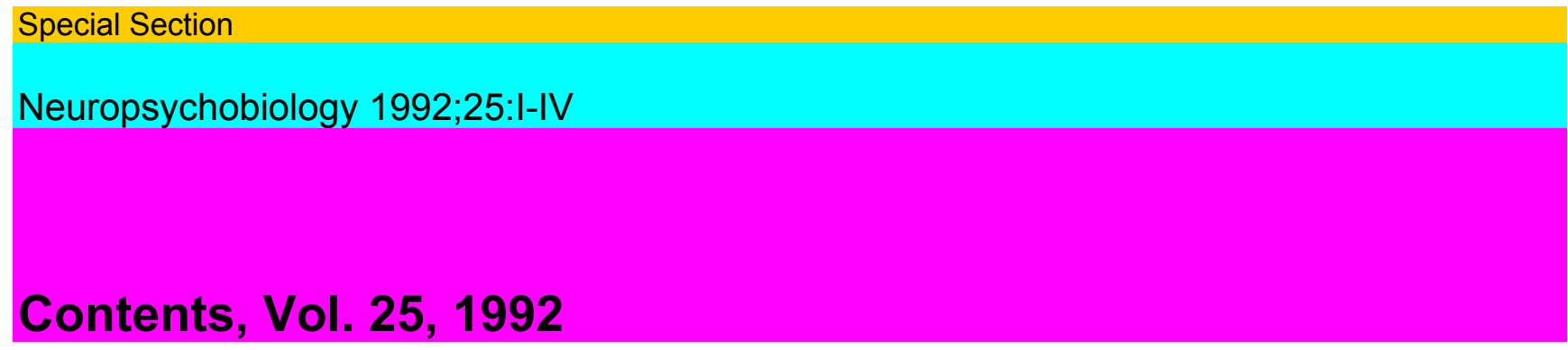

International Journal of Experimental and Clinical Research in Biological Psychiatry, Pharmacopsychiatry, Biological Psychology/Pharmacopsychology and Pharmacoelectroencephalography

Founded 1975 by J. Mendlewicz (Brussels).

Since 1983 integrating 'International Pharmacopsychiatry',

founded 1968 by F.A. Freyhan (New York), N. Petrilowitsch (Mainz), P. Pichot (Paris)

\title{
Biological Psychiatry
}

Main Editor

J. Mendlewicz, Brussels

\section{Pharmacopsychiatry}

Main Editor

B. Saletu, Vienna

Associate Editors

H. Beckmann, Würzburg

K. Rickels, Philadelphia, Pa.

\section{Biological Psychology/ Pharmacopsychology}

Main Editor

W. Janke, Würzburg

Associate Editors

P.L. Carlton, Piscataway, N.J.

P. Netter, Giessen

D.M. Warburton, Early Gate, Reading

\section{Pharmacoelectroencephalography}

\section{Main Editor}

W.M. Herrmann, Berlin

Associate Editors H. Heinze, Hannover M. Fink, St. James, N.Y. M. Saito, Osaka 


\section{Advisory Board}

V. Albrecht, Prague

J. Angst, Zurich

Th.A. Ban, Nashville, Tenn.

J. Bock, Basel

W. Boucsein, Wuppertal

M. Bourin, Nantes

N. Brunello, Milan

M.S. Buchsbaum, Irvine, Calif.

R. Cespuglio, Lyon

A. Coppen, Epsom

R. Coppola, Washington, D.C,

J.-M. Danion, Strasbourg

J.R. Davis, Chicago, 111 .

G. Debus, Aachen

A. Delini-Stula, Lingolsheim

H. Deporteere, Bagneux

A.E. Dresse, Liè̀ge

G. Dumermuth, Zurich

G. Erdmann, Berlin

H.J. Eysenck, London

G. Ferber, Basel

A. Friederici, Berlin

J. Fritze, Köln

J.-M. Gaillard, Chêne-Bourg

S. Givens, Nutley, N.J.

J. Glowinski, Paris

F.K. Goodwin, Bethesda, Md.

P. Grof, Hamilton, Ont.

0 . Hagnell, Lund

U. Hegerl, Berlin

H. Heimann, Tubingen T. Helgason, Reykjavik D. Hellhammer, Trier

1. Hindmarch, Guildford

J.P. Huston, Düsseldorf

T.M. Itil, New York, N.Y.

P. Janssen, Beerse

M. Jobert, Berlin

F.N. Johnson, Lancaster

M. Jouvet, Lyon

K.W. Kallus, Würzburg

H. Kleinlogel, Hinterkappelen

F. Krijzer, Weesp

St. Kubicki, Berlin

J. Kugler, Munich

D. Kupfer, Pittsburgh, Pa.

M. Lader, London 
S.Z. Langer, Paris D. Lehmann, Zurich G.A. Lienert, Nürnberg J.J. Lopez İbor, Madrid H. Maier-Lenz, Sigmaringen J. Mathieson, Nutley, N.J. M. Matousek, Göteborg N. Matussek, Munich H.Y. Meltzer, Cleveland, Ohio S. Montgomery, London T.F. Münte, Hannover T. Nagatsu, Nagoya K. Pawlik, Hamburg J.M. Perel, Pittsburgh, Pa.

C. Perris, Umeå

H. Petsche, Vienna

P. Pichot, Paris

W. Pöldinger, Basel

R. Pohl, Detroit, Mich.

A.J. Prange, Chapel Hill, N.C.

Ch. Pull, Luxembourg

G. Racagni, Milan

J.D. Rainer, New York, N.Y.

L. Ringwelski, Sigmaringen

M. Sandier, London

W.G. Sannita, Genova

N. Sartorius, Geneva

D. Schalling, Stockholm

R. Scherschlicht, Basel

R. Schlittgen, Hamburg

F. Schulsinger, Copenhagen

H. Schulz, Berlin

Ch. Shagass, Philadelphia, Pa.

R. Tissot, Geneva

H.M. Van Praag, Maastricht

M. Vartanian, Moscow

A. Villeneuve, Beauport, Que.

O. Vinar, Prague

W. Vogel, Philadelphia, Pa.

K.H. Voigt, Marburg

M. Vojtëchovsky, Prague

A. Wauqier, Toledo, Ohio

G. Winokur, Iowa City, Iowa

B. Woggon, Zurich

H. Yamadera, Tokio

M.B.H. Youdim, Haifa 
S. Karger

Medical and Scientific Publishers Basel $\cdot$ Freiburg $\cdot$ Paris $\cdot$ London New York $\cdot$ New Delhi $\cdot$ Bangkok Singapore $\cdot$ Tokyo $\cdot$ Sydney 
Drug Dosage

The authors and the publisher have exerted every effort to ensure that drug selection and dosage set forth in this text are in accord with current recommendations and practice at the time of publication. However, in view of ongoing research, changes in government regulations, and the constant flow of information relating to drug therapy and drug reactions, the reader is urged to check the package insert for each drug for any change in indications and dosage and for added warnings and precautions. This is particularly important when the recommended agent is a new and/or infrequently employed drug. 
All rights reserved.

No part of this publication may be translated into other languages, reproduced or utilized in any form or by any means, electronic or mechanical, including photocopying, recording, microcopying, or by any information storage and retrieval system, without permission in writing from the publisher or, in the case of photocopying, direct payment of a specified fee to the Copyright Clearance Center (see 'Information for Readers and Subscribers')

(C) Copyright 1992 by S. Karger AG, P.O. Box, CH- 4009 Basel (Switzerland) Printed in Switzerland on acid-free paper by Thür AG Offsetdruck, Pratteln 
Contents Vol. 25,1992

No. 1 


\section{Biological Psychiatry}

Hypothalamic-Pituitary-Adrenal Axis Function in Chronic 1

Schizophrenia: Association with Clinical Features Kaneko, M.; Yokoyama, F.; Hoshino, Y.; Takahagi, K.; Murata, S.; Watanabe, M.; Kumashiro, $\mathrm{H}$.

Imipramine-Induced Jitteriness and Decreased Serum Iron

Levels

Yeragani, V.K.; Pohl, R.; Balon, R.; Ramesh, C; Weinberg, P.

Personality Features and Platelet 7/8lmipramine Binding

Castrogiovanni, P.; Maremmani, I.; Di Muro, A.; Rotondo, A.; Marazziti, D.

Platelet Alpha-2 Adrenergic Receptor Binding and Plasma Free 14 3-Methoxy-4-hydroxyphenyl-ethylene Glycol in Depressed Patients before and after Treatment with Mianserin Kaneko, M.; Kanno, T.; Honda, K.; Mashiko, H.; Oosuga, N.; Watanabe, A.; Kumashiro, H.

Relationships between Psychomotor Retardation and EEG

Power Spectrum in Major Depression Nieber, D.; Schlegel, S.

\section{Pharmacopsychlatry}

Clinical Studies with Oxiracetam in Patients with Dementia of 24 Alzheimer Type and Multi-Infarct Dementia of Mild to Moderate Degree Villardita, C; Grioli, S.; Lomeo, C; Cattaneo, C; Parini, J.

Effects of Sulpiride and Oxypertine on the Dopaminergic

System in the Rat Striatum

Motohashi, N.; Takashima, M; Mataga, N.; Nishikawa, T.; Ogawa, A.; Watanabe, S.; Toru, M.

\section{Biological Psychology/Pharmacopsychology}

Cigarette Smoking and Nicotine Gum (0, 2 and $4 \mathrm{mg})$ :

Effects upon Four Visual Attention Tasks Parrott, A.C.; Craig, D.

Behavioral Restraint and Symptoms of Attention Deficit Dis- 44 order in Alcoholics and Pathological Gamblers Carlton, P.L.; Manowitz, P.

\section{Pharmacoelectroencephalography}

Placebo Effects in Standard Human Neuropharmacological 49

Studies: Effects of Physiological Variations of Blood Glucose and Ammonia Concentration on the Electrophysiology of the Visual System Sannita, W.G.; Balestra, V.; DiBon, G.; Hassan, K.M.; Rosadini, G. 


\section{Pharmacoelectroencephalography}

Abstracts of the 7th IPEG Symposium, Boca Raton, Fla., $\quad 61$ May 23-25, 1992

Attenuated Late Positivity in the Visual Evoked Potential in 83

Aphasia Induced by Lesions in Anterior Speech Area Behari, M.; Rao, P.S.; Verma, A.

Serotonergic Inhibition of Limbic and Thalamic Seizures in

Cats

Wada, Y.; Hasegawa, H.; Nakamura, M.; Yamaguchi, N.

\section{Biological Psychiatry}

Leftward Shift of R-Axis on Electrocardiogram in Patients with 91

Panic Disorder and Depression

Yeragani, V.K.; Balon, R.; Pohl, R.; Weinberg, P.; Thomas. S.

Lymphocyte Subsets in Major Depressive Patients. Influence 94

of Anxiety and Corticoadrenal Overdrive

Charles, G.; Machowski, R.; Brohee, D.; Wilmotte, J.; Kennes, B.

Abnormal Electroretinography in Schizophrenic Patients with 99 a History of Sun Gazing

Gerbaldo, H.; Thaker, G.; Tittel, P.G.; Layne-Gedge, J.; Moran, M.; Demisch, L.

Quantitative Electroencephalography in Parkinson's Disease, 102 Dementia, Depression and Normal Aging Primavera, A.; Novello, P.

\section{Biological Psychology/Pharmacopsychology}

Neuroendocrine Responses to a Glucose Challenge in Sub-

106

stance Users with High and Low Levels of Aggression, Impul-sivity, and Antisocial Personality Fishbein, D.H.; Dax, E.; Lozovsky, D.B.; Jaffe, J.H.

Saliva Cortisol Responses to Unpleasant Film Stimuli Differ 115 between High and Low Trait Anxious Subjects Hubert, W.; de Jong-Meyer, $\mathrm{R}$ 
No. 3 
No. 4

\section{Biological Psychiatry}

Effect of Plasma from Premenstrual Syndrome and Control $\quad 121$

Patients on Human Platelet and Rat Brain Synaptosome Monoamine Oxidase B Activity Ashby, C.R., Jr.; Carr, L.A.; Cook, G; Steptoe, MM.; Franks, D.D.

Plasma Free 3-Methoxy-4-Hydroxyphenylglycol in Acute 126

Schizophrenics before and after Treatment Kaneko, M.; Honda, K.; Kanno, T.; Horikoshi, R.; Manome, T.; Watanabe, A.; Kumashiro, H.

Electroconvulsive Therapy-Induced Cortisol Release after 130

Dexamethasone in Depression Swartz, CM.

\section{Pharmacopsychiatry}

Residual Effects of Repeated Administration of Triazolam and 134

Nitrazepam in Healthy Volunteers

Muraoka, M.; Tada, K.; Nogami, Y.; Ishikawa, K.; Nagoya, T.

Clinical Safety and Efficacy of Tianeptine in 1,858 Depressed 140 Patients Treated in General Practice Guelfi, J.D.; Dulcire, C; Le Moine, P.; Tafani, A.

The Rabbit Syndrome and Antiparkinsonian Medication in 149 Schizophrenic Patients Wada, Y.; Yamaguchi, N.

\section{Biological Psychology/Pharmacopsychology}

Selective Effects of Colds and Influenza on Human Perfor-

mance Efficiency: A Critical Appraisal Savory, M.A.

Cognitive and Psychomotor Function during Severe Insulin- 161 Induced Hypoglycaemia in Insulin-Dependent Diabetic

Patients

Lingenfelser, T.; Overkamp, D.; Renn, W.; Hamster, W.; Boughey, J.; Eggstein, M.; Jakober, B.

\section{Pharmacoelectroencephalography}

Effects of Age on Event-Related Potentials in Chronic Alcoholics: A Multimodal Study

Cadaveira, F.; Roso, M.; Grau, C; Sánchez-Turet, M.

Strange Attractors, Chaotic Behavior and Informational Aspects of Sleep EEG Data Röschke, J. 


\section{Biological Psychiatry}

Grade II and Grade III Hypothyroidism in Rapid-Cycling

Bipolar Patients

Kusalic, M.

Acutely Administered Haloperidol-Induced Pattern Changes of 182 Regional Cerebral Blood Flow in Schizophrenics. Observation from Subtraction of Brain Imaging with Single Photon Emission Computed Tomography Using Technetium-99m Hexamethyl-Propyleneamine Oxime Jibiki, I.; Matsuda, H.; Yamaguchi, N.; Kurokawa, K,; Hisada, K.

Twenty-Four-Hour Beta-Endorphin Secretory Pattern in

188

Alzheimer's Disease

Rolandi, E.; Gandolfo, C; Franceschini, R.; Cataldi, A.; Garibaldi, A.; Barreca, T.

\section{Pharmacopsychiatry}

Use of Buspirone in Patients with Generalized Anxiety Disor- 193 der and Coexisting Depressive Symptoms. A Meta-Analysis of Eight Randomized, Contolled Studies

Gammans, R.E.; Stringfellow, J.C.; Hvịzdos, A.J.; Seidehamel, R.J.; Cohn, J.B.; Wilcox, C.S.; Fabre, L.F.; Pecknold, J.C.; Smith, W.T.; Rickels, K.

Tricyclic Antidepressant Plasma Levels after Fluoxetine 202

Addition

Vandel, S.; Bertschy, G.; Bonin, B.; Nezelof, S.; Francois, T.H.;

Vandel, B.; Sechter, D.; Bizouard, P.

\section{Biological Psychology/Pharmacopsychology}

Thyroid Hormone Correlates of Sensation Seeking and Anxiety 208 in Healthy Human Females Balada, F.; Torrubia, R.; Arqué, J.M.

\section{Pharmacoelectroencephalography}

Influence of Quinidine on the Pharmacokinetics of 214

Trimipramine and on Its Effect on the Waking EEG of Healthy Volunteers. A Pilot Study on Two Subjects Eap, C.B.; Laurian, S.; Souche, A.; Koeb, L.; Reymond, P.; Buclin, T.; Baumann, P.

Effect of Carbamazepine Treatment on EEG Changes Induced 221 by Different Cortical Activation Patterns in Newly Referred Epileptic Patients

Marciani, M.G.; Stefanini, F.; Stefani, N.; Sabbadini, M.; Gigli, G.L.; Bernardi, G.

A Method for Comparing Benzodiazepine Pharmacodynamics 227 in the Human Brain MacNeill, B.; Gaetz, M.; Ancill, R.

$\begin{array}{ll}\text { Announcements } & 192 \\ \text { Author Index } & 230 \\ \text { Subject Index } & 231\end{array}$


